\title{
To Fill or Not to Fill? - Value of the Administration of Positive Rectal Contrast for CT Evaluation of Diverticular Disease of the Colon
}

\author{
Füllen oder nicht? - Wertigkeit der rektalen Gabe positiven \\ Kontrastmittels im Rahmen der CT zur Evaluation \\ der Divertikelkrankheit des Dickdarms
}

Authors

Simone Meyer, Martina Schmidbauer, Frank K. Wacker, Kristina Imeen Ringe

Affiliation

Department of Diagnostic and Interventional Radiology, Hannover Medical School, Hannover, Germany

Key words

diverticular disease, diverticulitis, colon, contrast, CT

received 23.09 .2020

accepted 02.12.2020

published online 03.02 .2021

Bibliography

Fortschr Röntgenstr 2021; 193: 804-812

DOI 10.1055/a-1339-2157

ISSN 1438-9029

(C) 2021. Thieme. All rights reserved.

Georg Thieme Verlag KG, Rüdigerstraße 14,

70469 Stuttgart, Germany

\section{Correspondence}

Prof. Kristina Imeen Ringe

Institut für Diagnostische und Interventionelle Radiologie,

Medizinische Hochschule Hannover, Carl-Neuberg-Straße 1,

30625 Hannover, Germany

Tel.: $+49 / 511 / 5323424$

Fax: $+49 / 511 / 5323885$

ringe.kristina@mh-hannover.de

\section{ZUSAMMENFASSUNG}

Ziel Evaluation der rektalen Gabe positiven KM im Rahmen der CT bei Patienten mit klinischem Verdacht auf Divertikelkrankheit des Dickdarms (DD).

Material und Methoden 460 Patienten (253 Männer, 207 Frauen; medianes Alter 62 Jahre; Interquartilsabstand 24) mit klinischem Verdacht auf DD wurden in diese retrospektive, durch die Ethikkommission genehmigte Studie eingeschlossen. Die CT wurde nur mit i.v. KM ( $n=328$, Gruppe M1), i.v. und positivem rektalem $\mathrm{KM}(\mathrm{n}=82$, Gruppe M2), weder i. v. noch positivem rektalem KM $(n=32$, Gruppe S1) oder nur positivem rektalem KM ( $n=18$, Gruppe S2) durchgeführt. Die CT-Untersuchungen wurden von 2 Radiologen gemeinsam im Hinblick auf die Diagnose DD (ja/nein) evaluiert und, falls zutreffend, basierend auf der
Klassifikation der Divertikelkrankheit (CDD) kategorisiert. Als Referenzstandard dienten der klinische Verlauf $(n=335)$ sowie der operative/histologische Befund $(n=125)$. Sensitivität, Spezifität, positiver (PPV) und negativer prädiktiver Wert (NPV) wurden für alle Gruppe berechnet. Im Fall einer Operation wurde das CT-Stadium mit dem histopathologischen Ergebnis korreliert (gewichtete Cohen-k).

Ergebnisse Bei 224 Patienten (48,7\%) wurde eine DD diagnostiziert. Sensitivität, Spezifität, PPV und NPV für die CT waren wie folgt: Gruppe M1 / M2: $92 \% / 92 \%, 97 \% / 94 \%, 96 \% / 96 \%$, $94 \% / 89 \%$; Gruppe S1/S2: $94 \% / 86 \%$, $93 \% / 80 \%$, $94 \% / 92 \%$, $93 \% / 67 \%$. Das CT-Stadium korrelierte in allen Gruppen sehr gut mit dem histopathologischen Befund ( $k=0,748-0,861)$.

Schlussfolgerung Die CT hat eine hohe Sensitivität und Spezifität für die Diagnose einer Divertikelkrankheit des Dickdarms. Das radiologische Krankheitsstadium korrelierte sehr gut mit dem intraoperativen Befund. Die ergänzende rektale Applikation von positivem KM hat jedoch in der vorliegenden Studie keinen signifikanten Vorteil gezeigt, sodass im Rahmen der klinischen Routine auf diese verzichtet werden kann.

Kernaussagen:

- Die CT hat eine hohe Sensitivität/Spezifität für die Diagnose DD.

- Das CT-Stadium (CDD Algorithmus) korreliert sehr gut mit dem operativen Befund.

- Die Gabe von positivem rektalen KM verbessert weder Diagnose noch Stadieneinteilung.

\section{ABSTRACT}

Purpose To assess the value of the administration of positive rectal contrast at $\mathrm{CT}$ in patients referred for suspected diverticular disease (DD) of the colon.

Materials and Methods 460 patients (253 male, $207 \mathrm{fe}$ male; median age 62 years; interquartile range 24 ) with clinical suspicion of DD of the colon were included in this retrospective IRB-approved study. CT was performed with i.v. contrast only ( $n=328$, group M1), i. v. + positive rectal contrast ( $n=82$, group $M 2)$, neither i.v. nor rectal contrast $(n=32$, group $S 1)$, or positive rectal contrast only $(n=19$, group S2). Two readers in consensus evaluated all CT datasets concerning diagnosis of DD (yes/no) and categorized findings 
(classification of diverticular disease (CDD)). Sensitivity, specificity, positive (PPV) and negative (NPV) predictive values for the diagnosis of DD were calculated for all groups, using either clinical follow-up ( $n=335)$ or intraoperative findings $(n=125)$ as the reference standard. In patients undergoing surgery, radiological staging of DD was correlated with the histopathology (weighted Cohen-k).

Results 224 patients (48.7\%) were diagnosed with DD. The sensitivity, specificity, PPV, and NPV were as follows. Group M1 / M2: $92 \% / 92 \%$, 97\%/94\%, $96 \% / 96 \%$, $94 \% / 89 \%$, respectively; group S1 / S2: $94 \% / 86 \%$, $93 \% / 80 \%$, $94 \% / 92 \%$, $93 \% / 67 \%$, respectively. Radiological staging and histopathology correlated substantially in all groups $(\mathrm{k}=0.748-0.861)$.

Conclusion Abdominal CT had a high sensitivity and specificity for the diagnosis of DD. Disease staging correlated well with the findings at surgery. Additional positive rectal contrast administration did not have a significant advantage and may therefore be omitted in patients with suspected DD.

\section{Key Points:}

- CT has a high sensitivity and specificity for diagnosis of DD.

- CT staging using the CDD algorithm correlates very well with surgery.

- Positive rectal contrast administration does not improve diagnosis and radiological staging.

\section{Citation Format}

- Meyer S, Schmidbauer M, Wacker FK et al. To Fill or Not to Fill? - Value of the Administration of Positive Rectal Contrast for CT Evaluation of Diverticular Disease of the Colon. Fortschr Röntgenstr 2021; 193: 804-812

\section{Introduction}

Diverticulosis, i. e. the presence of asymptomatic false diverticula in the gastrointestinal tract, has a high prevalence of about $30 \%$ in patients $50-70$ years and up to $66 \%$ in patients older than 85 years [1]. Approximately $15-20 \%$ of patients develop clinical symptoms, defined as diverticular disease (DD). $75 \%$ of symptomatic patients have pain, $1-2 \%$ require hospitalization and about $0.5 \%$ require surgery [2]. Furthermore, up to $30 \%$ of symptomatic patients present with complicated DD (i. e., abscess or perforation). Therefore, diverticulitis accounts for the most frequent surgically treated disease after cancer in modern western countries [3, 4].

Different classifications for the staging of DD have been in use, e. g. the Hinchey classification [5] and the Hansen and Stock classification [6]. More recently, a new radiological classification of diverticular disease (CDD) has been proposed [7]. Based on this new algorithm, patients may be stratified into the following categories: outpatient care, in-house therapy, and surgical treatment. In this context, the accurate diagnosis and staging of DD is crucial for appropriate therapy and is a prerequisite to avoid insufficient or excessive treatment. Several national and international guidelines attest that cross-sectional imaging in terms of CT and ultrasound has very high diagnostic accuracy for the diagnosis of DD, and CT has been advocated as indispensable, especially if ultrasound is inconclusive and to rule out other differential diagnoses [8-10]. However, the CT technique with respect to the need for and type of contrast is often not specified in these guidelines. Still, many publications and studies advocate the use of oral and/or rectal contrast for the appropriate diagnosis of DD [11-13]. On the other hand, especially oral or rectal contrast administration may result in an unnecessary delay of diagnostic imaging [14].

To sum up, despite a high prevalence of DD in the general population, there is no consensus regarding the necessity of contrast administration for evaluation. This may also be due to a lack of high-quality comparative studies and a lack of detailed imaging recommendations regarding contrast administration in national and international guidelines. The purpose of our study was there- fore to assess the added value of rectal contrast administration in patients with DD. Specifically, we wanted to test the null hypothesis, that CT scans without rectal contrast are not inferior to CT scans with rectal contrast with regards to diagnostic accuracy in patients referred for diagnosis of diverticular disease.

\section{Materials and Methods}

\section{Patients}

This retrospective study was approved by the local Institutional Review Board with a waiver of patient consent granted. The Radiology Information System (RIS) of Hannover Medical School (blinded for review) was searched for patients referred to CT because of clinically suspected DD between June 2005 and October 2015. The inclusion criteria were as follows: age $\geq 18$ years, diagnostic CT scan, surgical or clinical follow-up of at least 4 weeks. The exclusion criteria were non-diagnostic CT scan and no available follow-up.

\section{CT technique}

Abdominal CT scans were acquired on a 64-slice (VCT; $n=398$ ) or 16-slice (LightSpeed; $n=62$ ) scanner (both GE HealthCare; both slice thickness $1.25 \mathrm{~mm}$ ) with patients in supine position. Intravenous contrast ( $88 \mathrm{ml}$ Imeron 350, Bracco Imaging; flow rate $3.5 \mathrm{ml} / \mathrm{sec}$ ) was administered and image acquisition started $15 \mathrm{sec}$ onds after bolus detection in the spleen (threshold $250 \mathrm{HU}$ ) [15]. In patients at risk (e.g., known contrast allergy or impaired kidney function) i. v. contrast injection was omitted. Rectal contrast was applied at the discretion of the radiologist in charge. In respective patients, up to $1000 \mathrm{ml}$ of a 1:10 diluted water-soluble contrast agent (Gastrografin, Bayer Healthcare) were administered via a gravity drip into the colon using a blocked balloon catheter [15]. Based on differences regarding contrast administration, this study was divided into two parts, as demonstrated in > Fig. 1. Patients with i. v. contrast were included in the main study, while patients who did not receive i. v. contrast were included in the supplementary study. 


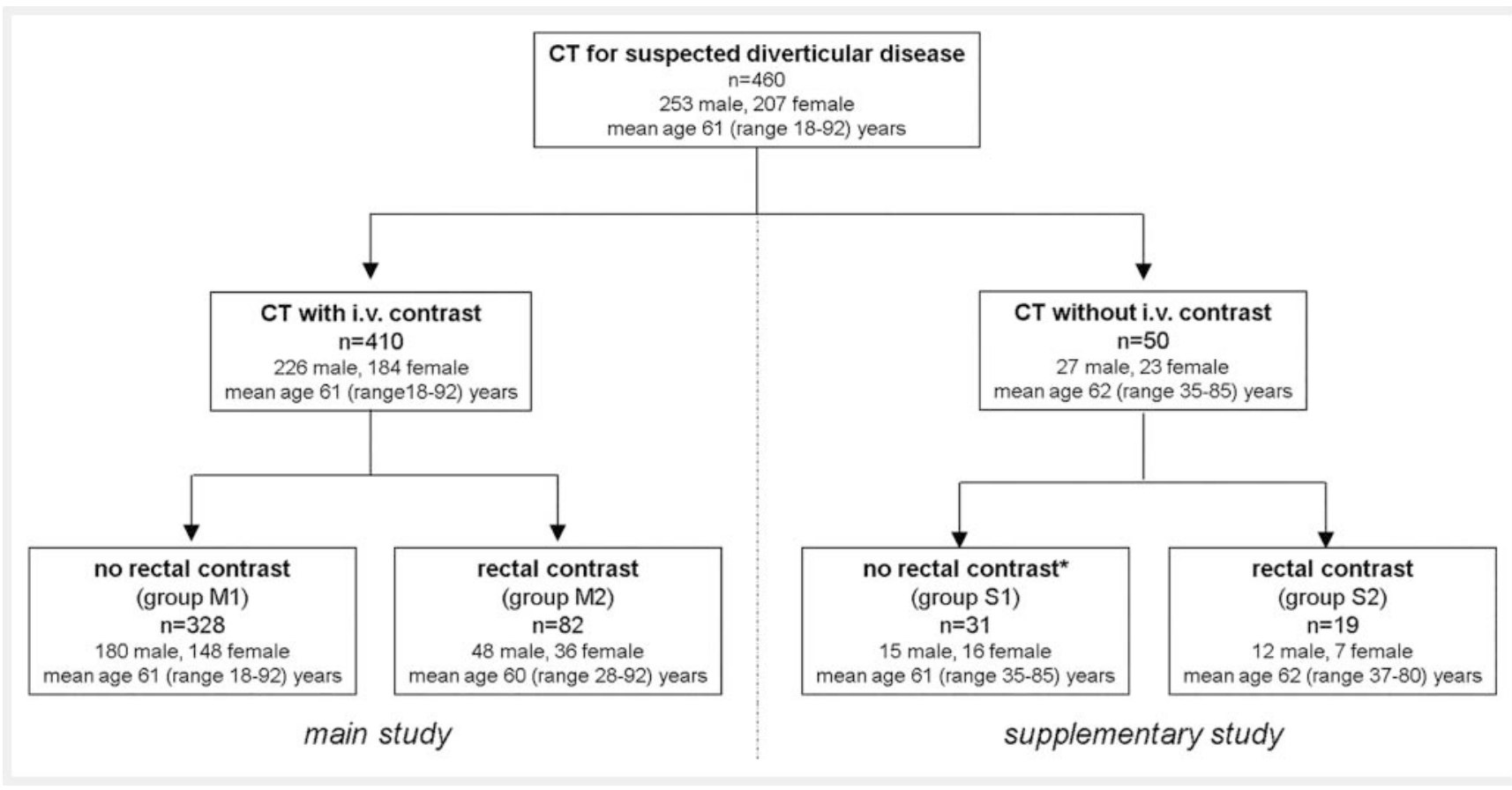

- Fig. 1 Flowchart demonstrating inclusion of patients referred for $\mathrm{CT}$ evaluation of suspected diverticular disease. Based on whether i. v. contrast was used or not, patients were assigned either to the main or to the supplementary study. ${ }^{*}$ includes 7 low-dose scans.

- Abb. 1 Übersicht der Patienten, welche einer CT-Untersuchung bei klinischem V. a. Divertikulitis erhielten. Basierend auf einer erfolgten oder fehlenden intravenösen KM-Gabe wurden die Patienten entweder in die Haupt- oder Zusatzstudie eingeschlossen. *beinhaltet 7 Low-dose-Untersuchungen.

\section{CT evaluation}

Image evaluation was performed on a commercially available workstation (Visage 7.1, Pro Medicus Inc). One board-certified radiologist (12 years of experience with abdominal $\mathrm{CT}$ ) and one $4^{\text {th }}$ year radiology resident in consensus reviewed all images with regard to the presence of DD or an alternative diagnosis. Transverse images as well as multiplanar reformations were used for evaluation. If diverticular disease was present, findings were classified using the newly proposed CDD algorithm [7], which is clearer than the Hansen-Stock or Hinchey classification with respect to radiological diagnosis [7]. Type 0: diverticulosis; type I: acute uncomplicated diverticulitis (la: no reaction of surrounding tissue; Ib: phlegmonous reaction of surrounding tissue); type 2: acute complicated diverticulitis (Ila: microabscess; Ilb: macroabscess; Ilc: free perforation), type III: chronic recurrent diverticulitis (IIla: symptomatic uncomplicated DD, SUDD; IIIb: recurrent diverticulitis without complications; Illc: recurrent diverticulitis with complications) and type 4: diverticular bleeding.

\section{Patient follow-up}

Electronic medical records were reviewed by the authors and patients were followed up for at least 4 weeks, especially with regard to the final clinical diagnosis (confirmation of DD or alternative diagnosis). In patients undergoing surgery, the radiological findings and staging of DD were correlated with intraoperative and histopathological staging, respectively. In conservatively treated patients clinical follow-up was the reference standard.

\section{Statistical analysis}

Statistical analysis was performed using GraphPad Prism 7 (GraphPad Software Inc.). To test for potential differences regarding age, sex, CRP value, and white blood cell between patients between the groups without and with rectal contrast in both study parts, the Mann-Whitney test and Fisher's exact test were used (after exclusion of a Gaussian and equal distribution using the D'Agostino and Pearson normality test). A post-hoc power analysis was performed using $G^{*}$ Power 3.1 (Heinrich-Heine University, Düsseldorf). Assuming an $\alpha$-error of 0.05 , an effective size $f$ of 0.25 , and a sample size of 410 patients for the main study (CT with i. v. contrast), the calculated power is 0.999 . With a sample size of $50 \mathrm{pa}$ tients, the calculated power of the supplementary study (without. i. v. contrast) is 0.410 . The accuracy, sensitivity, specificity, and positive (PPV) and negative predictive value (NPV) for the CT diagnosis of DD were calculated in each group. In patients undergoing surgery, CT staging of DD was correlated with intraoperative and histopathological findings using a weighted Cohen-k statistic. k-values were interpreted as follows: a value less than 0.20 indicated poor agreement; a value between 0.21 and 0.40 fair agreement; a value between 0.41 and 0.60 moderate agreement; a value between 0.61 and 0.80 substantial agreement; a value between 0.81 and 1.00 almost perfect agreement [16]. For all measurements, $p<0.05$ indicated a significant difference. 


\section{Results}

A total of 460 patients (253 males, 207 females; mean age 62 years, range 18-92 years) with suspected DD of the colon referred for CT were included in this study. 224 patients were diagnosed with DD, based on clinical follow-up or surgical findings as the reference standard. This resulted in a prevalence of DD of $49.8 \%$. Examples of different patients diagnosed with DD using varying $\mathrm{CT}$ acquisition protocols are presented in > Fig. 2 .

\section{CT with i. v. contrast (main study)}

410 patients ( 226 males, 184 females; mean age 61 years, range 18-92 years) underwent CT with i. v. contrast injection. In 328 patients CT scans were acquired after i. v. contrast injection only (group M1), and in 82 patients additional rectal contrast was administered (group M2). Patient characteristics are presented in detail in $>$ Table 1. With regard to baseline characteristics (age, sex, CRP value and leukocytes), there were no significant differences between patients who received rectal contrast and those who did not.

\section{Diagnosis of DD}

193 patients were diagnosed with DD (prevalence 47\%), confirmed either by surgery ( $n=57 ; 29.5 \%$ ) or clinical follow-up ( $n=136 ; 70.5 \%$ ). In both groups, DD was most often localized in the sigmoid colon (81.4\%), followed by the left hemicolon ( $8.3 \%$ ), right hemicolon (6.2\%), and multifocal (3.1\%) and transverse coIon (1\%). The accuracy, sensitivity, specificity, PPV and NPV for studies with i. v. contrast only (group M1) and with rectal contrast (group M2) were as follows: 95\%/93\%, 92\%/92\%, 97\%/94\%, $96 \% / 96 \%$ and $94 \% / 89 \%$, respectively. The cumulated CT accuracy of the surgically relevant CDD stage 2 (a-c combined) was $88 \%$ (group M1: 84.8\%; group M2: 94.1\%). Looking only at patients with confirmed diagnosis of DD, the rate of true positives, true negatives, false positives, and false negatives for groups M1 and M2 were $91.7 \% / 91.8 \%, 97.3 \% / 93.9 \%, 2.7 \% / 6.1 \%$ and $8.3 \% / 8.2 \%$, respectively ( $>$ Table 2 ).

\section{Staging of DD}

Out of 106 patients who underwent surgery, 57 patients were diagnosed with DD. At CT, most of these patients were classified as DD type IIb $(n=17)$ or Ilc $(n=21)$ according to the CDD algorithm. There was almost perfect agreement of staging between CT and intraoperative/histopathological findings, as indicated by a k-value of 0.823 for all CT scans with i. v. contrast. At subgroup analysis, there was also almost perfect agreement and substantial agreement for CT without rectal contrast ( $k=0.861$, group $M 1$ ) and $C T$ with rectal contrast $(k=0.782$, group $M 2)$, respectively ( $\triangleright$ Table 3). False-positive CT diagnoses of DD included one patient with colon cancer ( $\triangleright$ Fig. 3), one patient with appendicitis (both group M1) and one patient with recurrent bladder carcinoma (group M2). One patient was diagnosed with free fluid and liver cysts on CT (intraoperative DD type Ila; group M1), one patient with an enterocutaneous fistula (intraoperative DD type IIIc, group M2) and another patient with a large bowel obstruction (intraoperative DD type Ila; group M2).
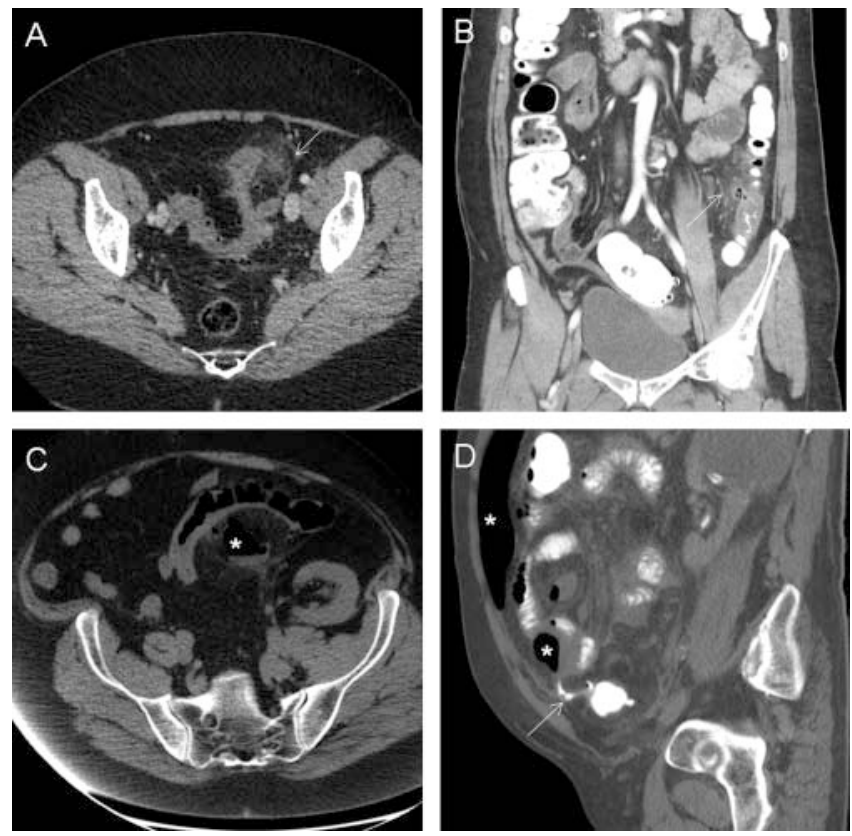

- Fig. 2 Presentation of diverticular disease in four different patients, using variable contrast administration protocols. A CDD stage Ib (i. v. contrast only) with reaction of surrounding fat tissue (open arrow). B CDD stage lb (i. v. and rectal contrast) with reaction of surrounding fat tissue (open arrow). C CDD stage IIb (neither i. v. nor rectal contrast) with depiction of a macroabscess $\left({ }^{*}\right)$. D CDD stage IIc (rectal contrast only) with depiction of extraluminal contrast (open arrow) and large amounts of free intraperitoneal gas ( ${ }^{*}$ ).

- Abb. 2 Beispiele verschiedener Patienten mit der Diagnose einer Divertikulitis im CT unter Anwendung unterschiedlicher Akquisitionsprotokolle. A CDD-Stadium Ib (nur i. v.-KM) mit Verdichtungen des perikolischen Fettgewebes (offener Pfeil). B CDD-Stadium IIb (i. v.und rektales KM) mit Verdichtungen des perikolischen Fettgewebes (offener Pfeil). C CDD-Stadium IIb (weder i. v.- noch rektales KM) mit Nachweis eines Makroabszesses $\left({ }^{*}\right)$. D CDD-Stadium IIc (nur rektales KM) mit Detektion von extraluminalem KM (offener Pfeil) und deutlichen Mengen freier Luft $\left(^{*}\right)$ intraperitoneal.

\section{CT without i. v. contrast (supplementary study)}

50 patients ( 27 males, 23 females; mean age 62 years, range 3585 years) underwent non-contrast-enhanced CT examinations, including 31 patients with neither i. v. nor rectal contrast (group S1) and 19 patients with rectal contrast only (group S2). With regard to baseline characteristics (age, sex, CRP value, and leukocytes), there were no significant differences between patients who received rectal contrast and those who did not ( $\vee$ Table 1 ).

\section{Diagnosis of DD}

31 patients were diagnosed with DD (prevalence 62\%), confirmed either by surgery $(n=12 ; 38.7 \%)$ or clinical follow-up $(n=19$; $61.3 \%$ ). DD was most often localized in the sigmoid colon (71\%). The accuracy, sensitivity, specificity, PPV, and NPV for studies without (group S1) and with rectal contrast (group S2) were $94 \% / 84 \%, 94 \% / 86 \%, 93 \% / 80 \%, 94 \% / 92 \%, 93 \% / 67 \%$, respectively ( $\triangleright$ Table 2$)$. 
- Table 1 Characteristics of patients undergoing CT for suspected diverticular disease.

- Tab.1 Charakteristiken der Patienten, welche aufgrund des klinischen Verdachts einer Divertikelkrankheit eine CT erhielten.

CT scans with i. v. contrast injection (main study)

\begin{tabular}{|c|c|c|c|}
\hline & $\begin{array}{l}\text { group M1 } \\
\text { (i. v. contrast) }\end{array}$ & $\begin{array}{l}\text { group M2 } \\
\text { (i. v. + rectal contrast) }\end{array}$ & statistical comparison \\
\hline number [n] & 328 & 82 & n.a. \\
\hline male/female [n] & $180 / 148$ & $48 / 36$ & $\mathrm{p}=0.81$ (Fisher's exact test) \\
\hline age [years] & $61(48-73)$ & $60(49-71)$ & $\mathrm{p}=0.84$ (MWU test) \\
\hline $\begin{array}{l}\text { CRP }[\mathrm{mg} / \mathrm{l}] \\
\text { (normal range } \leq 5 \text { ) }\end{array}$ & $104(25-156)$ & $101(30-152)$ & $\mathrm{p}=0.95$ (MWU test) \\
\hline $\begin{array}{l}\text { leukocytes [1000/I] } \\
\text { (normal range 3600-10500) }\end{array}$ & $11.7(7.8-14.9)$ & $11.7(8.4-14.8)$ & $\mathrm{p}=0.97$ (MWU test) \\
\hline prevalence of DD" [n] & $144(43.9 \%)$ & $49(59.8 \%)$ & n. a. \\
\hline \multicolumn{4}{|c|}{ CT scans without i. v. contrast injection (supplementary study) } \\
\hline & $\begin{array}{l}\text { group S1 } \\
\text { (no contrast) }\end{array}$ & $\begin{array}{l}\text { group S2 } \\
\text { (rectal contrast) }\end{array}$ & statistical comparison \\
\hline number [n] & 31 & 19 & n. a. \\
\hline male/female [n] & $15 / 16$ & $12 / 7$ & $\mathrm{p}=0.39$ (Fisher's exact test) \\
\hline age [years] & $61(51-72)$ & $62(51-75)$ & $\mathrm{p}=0.85$ (MWU test) \\
\hline $\begin{array}{l}\text { CRP [mg/l] } \\
\text { (normal range } \leq 5)\end{array}$ & $113(34-220)$ & $120(30-223)$ & $\mathrm{p}=0.7$ (MWU test) \\
\hline $\begin{array}{l}\text { leukocytes [1000/I] } \\
\text { (normal range 3600-10 500) }\end{array}$ & $13.9(9.7-16.7)$ & $10.6(6.4-13.6)$ & $\mathrm{p}=0.05$ (MWU test) \\
\hline prevalence of DD ${ }^{\#}[\mathrm{n}]$ & $17(54.8 \%)$ & $14(73.7 \%)$ & n. a. \\
\hline $\begin{array}{l}\text { Values are presented as total } \\
\text { disease; } C R P=C \text {-reactive prote } \\
\text { Die Angaben entsprechen abs } \\
\text { N. a. = nichtzutreffend, DD } D \\
\text { \# as confirmed either by follov } \\
\text { durch Verlauf oder OP bestä }\end{array}$ & $\begin{array}{l}\text { mean with interqu } \\
\text { (n) oder dem Mitt } \\
\text { heit; CRP = C-reakti } \\
\text { y. }\end{array}$ & $\begin{array}{l}\text { arentheses, if not stated } \\
\text { hörigem Interquartilbere }\end{array}$ & $\begin{array}{l}\text { = not applicable; } \mathrm{DD}=\text { divert } \\
\text { rn, sofern nicht anders angeg }\end{array}$ \\
\hline
\end{tabular}

\section{Staging of DD}

Out of 19 patients undergoing surgery, 11 patients were diagnosed with DD. For CT scans with neither i. v. nor rectal contrast, there was substantial agreement with intraoperative findings regarding the staging of DD $(\mathrm{k}=0.748)$. The agreement of rectal contrast-enhanced CT scans with surgery was similar $(k=0.759)$ ( $\vee$ Table 4, $\vee$ Fig. 4). The cumulated CT accuracy of the surgically relevant CDD stage 2 (a-c combined) was $100 \%$. In each group there was one false-positive diagnosis of DD at CT. Specifically, this included one patient staged as Ib DD (intraoperative found to have peritoneal carcinomatosis) and one patient staged as IIb DD (intraoperative diagnosis of recurrent urothelial carcinoma).

\section{Discussion}

In the present study, we demonstrated that CT without rectal and oral contrast has a very high sensitivity and specificity for the diagnosis of DD and enables reliable staging of disease severity. Therefore, we accept the null hypothesis that CT without rectal contrast is not inferior to scans with additional positive rectal contrast regarding diagnostic accuracy in patients referred for suspected DD. In a subgroup analysis, we were further able to demonstrate that this is true not only for scans with intravenous contrast enhancement, but also for CT scans without i. v. contrast injection.

The omission of oral and rectal contrast administration at CT has several advantages especially concerning clinical workflow and patient comfort. Oral contrast administration causes a diagnostic delay for the patient due to the time needed for ingestion of the contrast agent and gastrointestinal transport. In a randomized controlled trial by Garra et al., the median time to ingest 2 liters of an oral contrast agent was more than 100 minutes, potentially compromising individual patient safety in critical and timesensitive conditions [17]. Similarly, rectal contrast administration requires time, is dependent on patient compliance, and may aggravate patient discomfort (also as continence may be impaired, making adequate intraluminal filling improbable). Furthermore, administration of a positive contrast agent (rectally or orally) may mask the presence of abnormal bowel wall enhancement 
- Table 2 Performance of $\mathrm{CT}$ for the diagnosis of DD of the colon, with clinical follow-up or surgical findings as the reference standard.

- Tab.2 Abschneiden der CT im Hinblick auf die Diagnose Divertikelkrankheit des Dickdarms, basierend auf dem klinischen Verlauf oder dem operativen Befund als Referenzstandard.

\begin{tabular}{|c|c|c|c|c|c|c|}
\hline & $\begin{array}{l}\text { All } \mathrm{i} . \mathrm{v} \text {. } \\
\text { contrast CT }\end{array}$ & i. v. only & i. v. + rectal & $\begin{array}{l}\text { all non- } \\
\text { contrast CT }\end{array}$ & $\begin{array}{l}\text { non-contrast } \\
\text { CT }\end{array}$ & $\begin{array}{l}\text { rectal } \\
\text { contrast only }\end{array}$ \\
\hline & & (group M1) & (group M2) & & (group S1) & (group S2) \\
\hline accuracy & $94.4 \%$ & $94.8 \%$ & $92.7 \%$ & $90 \%$ & $93.5 \%$ & $84.2 \%$ \\
\hline sensitivity & $91.7 \%$ & $91.7 \%$ & $91.8 \%$ & $90.3 \%$ & $94.1 \%$ & $85.7 \%$ \\
\hline specificity & $96.8 \%$ & $97.3 \%$ & $93.9 \%$ & $90.9 \%$ & $92.9 \%$ & $80 \%$ \\
\hline PPV & $96.2 \%$ & $96.4 \%$ & $95.7 \%$ & $93.3 \%$ & $94.1 \%$ & $92.3 \%$ \\
\hline NPV & $93 \%$ & $93.7 \%$ & $88.6 \%$ & $87 \%$ & $92.9 \%$ & $66.7 \%$ \\
\hline true positives* & $91.7 \%$ & $91.7 \%$ & $91.8 \%$ & $90.3 \%$ & $94.1 \%$ & $85.7 \%$ \\
\hline true negatives* & $96.8 \%$ & $97.3 \%$ & $93.9 \%$ & $89.5 \%$ & $92.9 \%$ & $80 \%$ \\
\hline false positives* & $3.2 \%$ & $2.7 \%$ & $6.1 \%$ & $10.5 \%$ & $7.1 \%$ & $20 \%$ \\
\hline false negatives* & $8.3 \%$ & $8.3 \%$ & $8.2 \%$ & $9.7 \%$ & $14.3 \%$ & $5.9 \%$ \\
\hline $\begin{array}{l}\mathrm{PPV}=\text { positive } \mathrm{pr} \\
\mathrm{PPV}=\text { positiv prä } \\
{ }^{*} \text { calculations ref } \\
\text { Die Berechnun }\end{array}$ & $\begin{array}{l}\text { alue; NPV = ne } \\
\text { ert; NPV = ne } \\
\text { ents with con } \\
\text { hen sich nur a }\end{array}$ & $\begin{array}{l}\text { redictive value } \\
\text { diktiver Wert. } \\
\text { iagnosis of DL } \\
\text { ten mit best }\end{array}$ & & lkrankheit. & & \\
\hline
\end{tabular}

- Table 3 Correlation of i. v. contrast-enhanced CT findings and histopathology in patients undergoing surgery, with specific emphasis on DD type in respective cases.

- Tab.3 Korrelation von Befunden in der CT (mit i. v.-KM) und Histopathologie bei Patienten, welche einer operativen Therapie zugeführt wurden.

\begin{tabular}{|c|c|c|c|c|c|c|}
\hline & \multicolumn{2}{|c|}{$\begin{array}{l}\text { all i. v. contrast } \\
(n=106)\end{array}$} & \multicolumn{2}{|c|}{$\begin{array}{l}\text { i. v. only (group M1) } \\
(n=76)\end{array}$} & \multicolumn{2}{|c|}{$\begin{array}{l}\text { i. v. + rectal (group M2) } \\
(n=30)\end{array}$} \\
\hline & CT & surgery & $\mathbf{C T}$ & surgery & $\mathrm{CT}$ & surgery \\
\hline diagnosis of DD & $57(53.8 \%)$ & 57 (53.8\%) & 39 (51.3\%) & 38 (50\%) & 18 (60\%) & 19 (63.3\%) \\
\hline other diagnosis & 49 (46.2\%) & 49 (46.2 \%) & 37 (48.7\%) & 38 (50\%) & $12(40 \%)$ & $11(36.7 \%)$ \\
\hline \multicolumn{7}{|l|}{ DD stage } \\
\hline .0 & 0 & 0 & 0 & 0 & 0 & 0 \\
\hline - $1 a$ & 0 & 0 & 0 & 0 & 0 & 0 \\
\hline - $1 b$ & 6 & 3 & 6 & 3 & 0 & 0 \\
\hline - $2 a$ & 10 & 13 & 6 & 9 & 4 & 4 \\
\hline - $2 b$ & 17 & 22 & 11 & 15 & 6 & 7 \\
\hline $.2 c$ & 21 & 15 & 14 & 9 & 7 & 6 \\
\hline $\begin{array}{l}\text { cumulated accuracy } \\
\text { stage } 2\end{array}$ & $88 \%$ & & $84.4 \%$ & & $94.1 \%$ & \\
\hline - $3 a$ & 0 & 0 & 0 & 0 & 0 & 0 \\
\hline - $3 b$ & 2 & 1 & 2 & 1 & 0 & 0 \\
\hline$=3 c$ & 1 & 3 & 0 & 1 & 1 & 2 \\
\hline .4 & 0 & 0 & 0 & 0 & 0 & 0 \\
\hline $\begin{array}{l}\text { correlation CT and pa- } \\
\text { thology }\end{array}$ & \multicolumn{2}{|l|}{$k=0.832$} & \multicolumn{2}{|l|}{$k=0.861$} & \multicolumn{2}{|l|}{$k=0.782$} \\
\hline
\end{tabular}




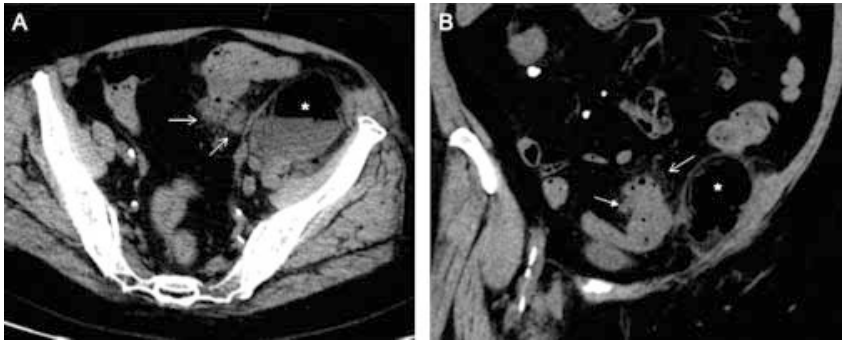

- Fig. 3 75-year-old female patient presenting to the emergency department with left lower quadrant pain (CRP $144 \mathrm{mg} / \mathrm{l}$, leucocytes $21.200 / I)$. CT with intravenous contrast in the axial $\mathbf{A}$ and coronal $\mathbf{B}$ plane depicts diverticula (arrow in B) in the sigmoid colon, discrete pericolic soft tissue changes (open arrows in $\mathbf{A}$ and $\mathbf{B}$ ) and a pericolic abscess with a gas-fluid level ( ${ }^{*}$ in $\mathbf{A}$ and $\mathbf{B}$ ). At $\mathrm{CT}$, patient was diagnosed as diverticular disease type IIb (macroabscess, contained perforation) and referred for surgery. Histopathological diagnosis showed a moderately differentiated adenocarcinoma with infiltration of the pericolic fat tissue and transmural inflammation.

- Abb. 3 75-jährige Patientin, die sich in der Notaufnahme mit Schmerzen im linken Unterbauch vorstellte (CRP 144 mg/l, Leukozyten 21 200/I). In der CT mit i. v.-KM in der transversalen $\mathbf{A}$ und koronaren $\mathbf{B}$ Ebene ist neben Sigmadivertikeln (Pfeil in B) und einer Verdichtung des perikolischen Fettgewebes (offene Pfeile in $\mathbf{A}$ und $\mathbf{B}$ ) ein perikolischer Abszess mit Luft-Flüssigkeitsspiegel ( ${ }^{*}$ in $\mathbf{A}$ und $\mathbf{B}$ ) erkennbar. Im CT wurde die Diagnose einer Divertikulitis Stadium IIb gestellt (Makroabszess, gedeckte Perforation) und die Patienten einer chirurgischen Therapie zugeführt. Histopathologisch ergab sich der Befund eines Adenokarzinoms mit Infiltration des perikolischen Fettgewebes und einer transmuralen Entzündung.

(e. g. in ischemia) or intestinal bleeding [18], impeding evaluation, especially with regard to differential diagnosis in patients presenting with acute abdominal pain. It has been postulated that colonic opacification helps to distinguish intraluminal air from fluid collections, e.g. in patients with (contained) perforated DD [12]. However, studies have shown that extraluminal contrast is only visible in a small number of patients with surgically proven alimentary tract perforation [19]. Incomplete luminal distention has been described as a common technical pitfall that can hamper discrimination of a true focal wall thickening from apparent wall thickening due to incomplete distention [11]. In our study, we did not find this to be a diagnostic problem especially concerning differentiation of acute complicated DD. On the other hand, enteric contrast administration may be beneficial for the assessment of fistula, e. g. in patients with recurrent DD [20], a circumstance that we did not specifically assess in our study.

To the best of our knowledge, no study has compared CT with and without rectal contrast specifically for the clinical workup of DD. A few studies have compared the value of CT with and without rectal/enteric contrast in patients with appendicitis [21] and in patients with acute non-traumatic pain [22], concluding that enteric contrast does not improve the radiological diagnosis in most patients [23]. The diagnostic accuracy (94.8\%), sensitivity (91.7\%), and specificity (97.3\%) of CT with i.v. contrast alone in our study are comparable with previous studies in patients with DD who underwent CT with varying enteric contrast protocols. Cho et al. reported a sensitivity of $93 \%$ in a small group of patients
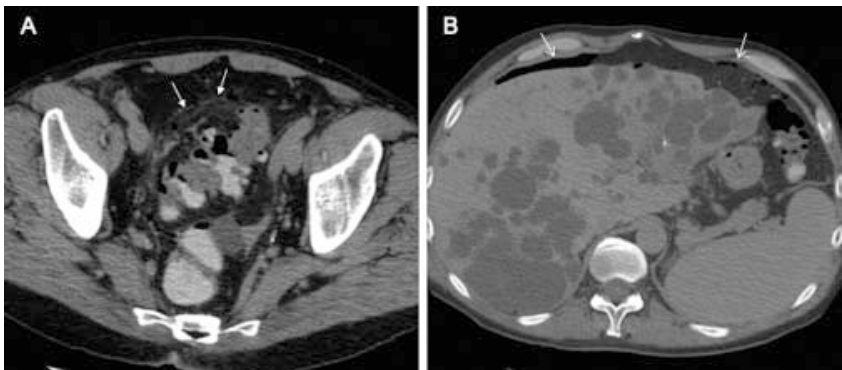

- Fig. 4 50-year-old male patient with polycystic kidney disease. The patient presented with an acute abdomen to the emergency room (CRP $198 \mathrm{mg} / \mathrm{l}$, leucocytes 8000/I). CT without intravenous but rectal contrast depicts gas-filled diverticula in the sigmoid colon with pericolic soft tissue changes (arrows in $\mathbf{A}$ ) and free gas (open arrows in $\mathbf{B}$ ) in the upper abdomen, consistent with diverticular disease type Ilc (free perforation). Findings were confirmed at surgery and patient underwent sigmoid resection. Of note, there is no extraluminal contrast.

- Abb.4 50-jähriger Patient mit polyzystischer Nierenerkrankung. Der Patient stellte sich mit einem akuten Abdomen in der Notaufnahme vor (CRP 198 mg/l, Leukozyten 8000/I). In der nativen CT mit rektalem KM sind luftgefüllte Divertikel im Sigma, perikolische Verdichtungen des Fettgewebes (Pfeile in $\mathbf{A}$ ) und freie Luft (offene Pfeile in B) im Oberbauch erkennbar, passend zu einer Divertikulitis Stadium IIc (freie Perforation). Der Befund bestätigte sich intraoperativ und der Patient erhielt eine Sigmaresektion. Zu beachten ist, dass kein KM-Extraintestinat nachweisbar ist.

(27 with DD) for CT scans with intravenous and oral contrast [24]. Ambrosetti et al. performed CT with intravenous, oral, and rectal contrast in patients with acute left colonic diverticulitis and found a sensitivity of $97 \%$ [25]. Similarly, in a prospective study of 120 patients with suspected left-sided diverticulitis, CT with intravenous and rectal contrast had an accuracy of $98 \%$, a sensitivity of $97 \%$, and a specificity of $98 \%$ [13]. To the best of our knowledge, there are only two recently published studies that evaluate the newly proposed CDD algorithm in correlation with intraoperative findings [26, 27]. While La Torre et al. found a high interobserver agreement of CT data between two radiologists $(k=0.905)$, the concordance of imaging and surgical findings was rather weak $(\mathrm{k}=0.213$ and 0.248$)$ [26]. In comparison, correlation with surgical findings was much higher in our study. A possible explanation for these distinctly differing results may be the lack of experience with this newer classification. Furthermore, La Torre et al. found a low sensitivity for the classification of stages 2c1 (purulent peritonitis) and 2c2 (fecal peritonitis), a differentiation we did not perform in our study. The low efficacy for the prediction of postoperative outcome also somehow contradicts a recently published prospective study by Lauscher and colleagues, who found that the CDD algorithm enables stratification of different types of diverticulitis in terms of course of treatment [27]. It has been noted that this new classification is clearer than the HansenStock or Hinchey classification with respect to radiological diagnosis and treatment-relevant categorization [7]. Implementation of this new classification in the clinical routine was straightforward in our experience. The chosen clinical follow-up of 4 weeks may have led to underestimation of chronic recurrent DD. There was a slight 
- Table 4 Correlation of non-contrast-enhanced CT findings and histopathology in patients undergoing surgery, with specific emphasis on DD type in respective cases.

- Tab.4 Korrelation von Befunden in der CT (ohne i. v.-KM) und Histopathologie bei Patienten, welche einer operativen Therapie zugeführt wurden.

\begin{tabular}{|c|c|c|c|c|c|c|}
\hline & \multicolumn{2}{|c|}{$\begin{array}{l}\text { all non-contrast } \\
(\mathrm{n}=19)\end{array}$} & \multicolumn{2}{|c|}{$\begin{array}{l}\text { no rectal contrast (group } S 1) \\
(n=10)\end{array}$} & \multicolumn{2}{|c|}{$\begin{array}{l}\text { with rectal contrast (group S2) } \\
(\mathrm{n}=9)\end{array}$} \\
\hline & CT & surgery & CT & surgery & CT & surgery \\
\hline diagnosis of DD & $14(73.7 \%)$ & $12(63.2 \%)$ & $6(60 \%)$ & $5(50 \%)$ & $8(88.9 \%)$ & 7 (77.8 \%) \\
\hline other diagnosis & $5(26.3 \%)$ & $7(36.8 \%)$ & $4(40 \%)$ & $5(50 \%)$ & $1(11.1 \%)$ & $2(22.2 \%)$ \\
\hline \multicolumn{7}{|l|}{ DD stage } \\
\hline . 0 & 0 & 0 & 0 & 0 & 0 & 0 \\
\hline - 1a & 0 & 0 & 0 & 0 & 0 & 9 \\
\hline - $1 b$ & 2 & 1 & 1 & 0 & 1 & 1 \\
\hline - $2 a$ & 0 & 1 & 0 & 0 & 0 & 0 \\
\hline - $2 b$ & 5 & 5 & 2 & 3 & 3 & 3 \\
\hline$=2 c$ & 5 & 4 & 3 & 2 & 2 & 2 \\
\hline cumulated accuracy stage 2 & $100 \%$ & & $100 \%$ & & $100 \%$ & \\
\hline - $3 a$ & 0 & 0 & 0 & 0 & 0 & 0 \\
\hline - $3 b$ & 1 & 1 & 0 & 0 & 1 & 1 \\
\hline - $3 c$ & 1 & 0 & 0 & 0 & 1 & 0 \\
\hline-4 & 0 & 0 & 0 & 0 & 0 & 0 \\
\hline correlation $\mathrm{CT}$ and pathology & \multicolumn{2}{|l|}{$k=0.772$} & \multicolumn{2}{|l|}{$k=0.748$} & \multicolumn{2}{|l|}{$k=0.759$} \\
\hline
\end{tabular}

tendency toward overstaging at CT in patients with stage IIb (acute complicated DD with macroabscess) in our study when compared with intraoperative findings. This trend toward overestimation in less pronounced inflammatory forms of diverticulitis was also reported in a study by Ritz et al. in 204 patients. They used the Hinchey classification and CT with intravenous, oral, and rectal contrast [28].

Our study does have some limitations, also due to the retrospective design. First, we did not assess the value of oral contrast in patients with suspected DD, but rather focused on rectal administration. Second, the diagnosis of DD was confirmed in most patients by means of clinical follow-up. This is due to the fact that DD is typically diagnosed clinically (clinical presentation in correlation with elevated (RP) and that patients with uncomplicated DD usually do not require surgery. Third, the group of patients without intravenous contrast administration (supplementary study) was small, as reflected also by the power analysis for this study part. However, the encouraging results in this cohort (including 7 patients with a non-contrast-enhanced low-dose protocol) warrant further investigation regarding the necessity of i. v. contrast and the accuracy of low-dose scans for patients with suspected DD, as has already been suggested [29]. Lastly, we did not look in detail at the value of rectal contrast administration for discriminating DD and colon cancer, which is the most important differential diagnosis.
In conclusion, the results of our study show that CT without rectal contrast administration has a high diagnostic accuracy in patients with suspected DD. Staging of disease severity using the recently proposed CDD algorithm correlates substantially with intraoperative findings. Adding rectal contrast administration did not contribute to diagnosis and staging. In this regard, it did not matter if scans were acquired with or without intravenous contrast. For the benefit of time, clinical workflow, and patient comfort, rectal contrast administration may thus be omitted in patients referred for suspected diverticular disease of the colon.

\section{CLINICAL RELEVANCE}

- CT has a high sensitivity and specificity for the diagnosis of DD.

- CT staging using the CDD algorithm correlates very well with surgery.

- Positive rectal contrast administration does not improve diagnosis and radiological staging.

\section{Conflict of Interest}

The authors declare that they have no conflict of interest. 


\section{References}

[1] Commane DM, Arasaradnam RP, Mills S et al. Diet, ageing and genetic factors in the pathogenesis of diverticular disease. World J Gastroenterol 2009; 15: 2479-2488

[2] Boynton W, Floch M. New strategies for the management of diverticular disease: insights for the clinician. Therap Adv Gastroenterol 2013; 6: 205-213

[3] Peery AF, Barrett PR, Park D et al. A high-fiber diet does not protect against asymptomatic diverticulosis. Gastroenterology 2012; 142: 266272, e261

[4] Ambrosetti P. Acute left-sided colonic diverticulitis: clinical expressions, therapeutic insights, and role of computed tomography. Clin Exp Gastroenterol 2016; 9: 249-257

[5] Hinchey E], Schaal PG, Richards GK. Treatment of perforated diverticular disease of the colon. Adv Surg 1978; 12: 85-109

[6] Hansen O, Graupe F, Stock W. Prognostic factors in perforating diverticulitis of the large intestine. Chirurg 1998; 69: 443-449

[7] Schreyer AG, Layer G. S2k Guid3lines for Diverticular Disease and Diverticulitis: Diagnosis, Classification, and Therapy for the Radiologist. Fortschr Röntgenstr 2015; 187: 676-684

[8] Leifeld L, Germer CT, Bohm S et al. S2k guidelines diverticular disease/ diverticulitis. Z Gastroenterol 2014; 52: 663-710

[9] Galgano S], McNamara MM. Expert Panel on Gastrointestinal Imaging et al. ACR Appropriateness Criteria Left Lower Quadrant Pain-Suspected Diverticulitis. J Am Coll Radiol 2019; 16: S141-S149

[10] Murphy T, Hunt RH, Fried M et al. Diverticular disease. Available at (accessed 2020 Jun 28): https://www.worldgastroenterologyorg/ UserFiles/file/guidelines/diverticular-disease-english-2007pdf

[11] Snyder M]. Imaging of colonic diverticular disease. Clin Colon Rectal Surg 2004; 17: 155-162

[12] Rao PM, Rhea JT, Novelline RA et al. Helical CT with only colonic contrast material for diagnosing diverticulitis: prospective evaluation of $150 \mathrm{pa}-$ tients. Am J Roentgenol 1998; 170: 1445-1449

[13] Werner A, Diehl SJ, Farag-Soliman M et al. Multi-slice spiral CT in routine diagnosis of suspected acute left-sided colonic diverticulitis: a prospective study of 120 patients. Eur Radiol 2003; 13: 2596-2603

[14] Broder JS, Hamedani AG, Liu SW et al. Emergency department contrast practices for abdominal/pelvic computed tomography - a national survey and comparison with the american college of radiology appropriateness criteria((R)). J Emerg Med 2013; 44: 423-433

[15] Prokop M, van der Molen AJ. Patientenvorbereitung und Konstratmittelapplikation. In: Prokop M, Galanski M, Schaefer-Prokop C, et al., (Hrsg) Ganzkörper-Computertomographie. Stuttgart: Georg-Thieme Verlag; 2007: 96-111
[16] Landis JR, Koch GG. The measurement of observer agreement for categorical data. Biometrics 1977; 33: 159-174

[17] Garra G, Singer AJ, Bamber D et al. Pretreatment of patients requiring oral contrast abdominal computed tomography with antiemetics: a randomized controlled trial of efficacy. Ann Emerg Med 2009; 53: 528533

[18] Kammerer S, Hoink A], Wessling J et al. Abdominal and pelvic CT: is positive enteric contrast still necessary? Results of a retrospective observational study. Eur Radiol 2015; 25: 669-678

[19] Maniatis V, Chryssikopoulos H, Roussakis A et al. Perforation of the alimentary tract: evaluation with computed tomography. Abdom Imaging 2000; 25: 373-379

[20] Liljegren G, Chabok A, Wickbom M et al. Acute colonic diverticulitis: a systematic review of diagnostic accuracy. Colorectal Dis 2007; 9: 480488

[21] Karam AR, Birjawi GA, Sidani CA et al. Alternative diagnoses of acute appendicitis on helical CT with intravenous and rectal contrast. Clin Imaging 2007; 31: 77-86

[22] Gourtsoyianni S, Zamboni GA, Romero JY et al. Routine use of modified CT Enterography in patients with acute abdominal pain. Eur J Radiol 2009; 69: 388-392

[23] Kessner R, Barnes S, Halpern P et al. CT for Acute Nontraumatic Abdominal Pain - Is Oral Contrast Really Required? Acad Radiol 2017; 24: 840-845

[24] Cho KC, Morehouse HT, Alterman DD et al. Sigmoid diverticulitis: diagnostic role of CT - comparison with barium enema studies. Radiology 1990; 176: 111-115

[25] Ambrosetti P, Grossholz M, Becker C et al. Computed tomography in acute left colonic diverticulitis. Br J Surg 1997; 84: 532-534

[26] La Torre M, Mingoli A, Brachini G et al. Differences between computed tomography and surgical findings in acute complicated diverticulitis. Asian J Surg 2020; 43: 476-481

[27] Lauscher JC, Lock JF, Aschenbrenner K et al. Validation of the German classification of Diverticular Disease (VADIS) - a prospective bicentric observational study. Int J Colorectal Dis 2020. doi:10.1007/s00384020-03721-9

[28] Ritz JP, Lehmann KS, Loddenkemper C et al. Preoperative CT staging in sigmoid diverticulitis - does it correlate with intraoperative and histological findings? Langenbecks Arch Surg 2010; 395: 1009-1015

[29] Tack D, Bohy P, Perlot I et al. Suspected acute colon diverticulitis: imaging with low-dose unenhanced multi-detector row CT. Radiology 2005; 237: 189-196 